\title{
Implication of tropical lower stratospheric cooling in recent trends in tropical circulation and deep convective activity
}

\author{
Kunihiko Kodera $^{1}$, Nawo Eguchi $^{2}$, Rei Ueyama ${ }^{3}$, Yuhji Kuroda ${ }^{1,4}$, Chiaki Kobayashi ${ }^{1}$, Beatriz M. Funatsu ${ }^{5}$, and \\ Chantal Claud $^{6}$ \\ ${ }^{1}$ Climate Research Department, Meteorological Research Institute, Tsukuba, 305-0052, Japan \\ ${ }^{2}$ Research Institute for Applied Mechanics, Kyushu University, Kasuga, 816-8580, Japan \\ ${ }^{3}$ Earth Science Division, Atmospheric Science Branch, NASA Ames Research Center, Moffett Field, CA 94035-0001, USA \\ ${ }^{4}$ Meteorological College, Japan Meteorological Agency, Kashiwa, 277-0852, Japan \\ ${ }^{5}$ CNRS, Université de Nantes, UMR 6554 LETG, Campus du Tertre, Nantes, 44312, France \\ ${ }^{6}$ Laboratoire de Météorologie Dynamique, Ecole Polytechnique, Palaiseau, 91128 , France
}

Correspondence: Kunihiko Kodera (kodera.kk@gmail.com)

Received: 4 February 2018 - Discussion started: 16 February 2018

Revised: 5 January 2019 - Accepted: 2 February 2019 - Published: 28 February 2019

\begin{abstract}
Large changes in tropical circulation from the mid-to-late 1990s to the present, in particular changes related to the summer monsoon and cooling of the sea surface in the equatorial eastern Pacific, are noted. The cause of such recent decadal variations in the tropics was studied using a meteorological reanalysis dataset. Cooling of the equatorial southeastern Pacific Ocean occurred in association with enhanced cross-equatorial southerlies that were associated with a strengthening of the deep ascending branch of the boreal summer Hadley circulation over the continental sector connected to stratospheric circulation. From boreal summer to winter, the anomalous convective activity center moves southward following the seasonal march to the equatorial Indian Ocean-Maritime Continent region, which strengthens the surface easterlies over the equatorial central Pacific. Accordingly, ocean surface cooling extends over the equatorial central Pacific. We suggest that the fundamental cause of the recent decadal change in the tropical troposphere and the ocean is a poleward shift of convective activity that resulted from a strengthening of extreme deep convection penetrating into the tropical tropopause layer, particularly over the African and Asian continents and adjacent oceans. We conjecture that the increase in extreme deep convection is produced by a combination of land surface warming due to increased $\mathrm{CO}_{2}$ and a reduction of static stability in the tropical tropopause layer due to tropical stratospheric cooling.
\end{abstract}

\section{Introduction}

Large changes in tropical circulation occurred from the midto-late 1990 s to the present, in particular changes related to the summer monsoon and cooling of the sea surface in the equatorial eastern Pacific. Such a decrease in the tropical east Pacific sea surface temperature (SST) has been associated with a slowdown, or hiatus, of global warming (Kosaka and Xie, 2013; England et al., 2014; Trenberth et al., 2014; Watanabe et al., 2014). Changes were also found in the advancement of the onset of the Asian summer monsoon (Kajikawa et al., 2012; Gautam and Regmi, 2013; Xiang and Wang, 2013; Yun et al., 2014) and an increase in precipitation over the Sahel in West Africa (Fontaine et al., 2011; Brandt et al., 2014; Maidment et al., 2015; Diawara et al., 2016). An increase in precipitation in southern Africa was also observed during austral summer (Vizy and Cook, 2016). In addition to these large-scale circulation changes, variations occurred in mesoscale phenomena such as an increase in mesoscale convective systems (MCSs) over the Sahel (Taylor et al., 2017). A relationship between tropopause layer cooling and tropical cyclone activity in the Atlantic has also been suggested (Emanuel et al., 2013). Indeed, recent numerical model studies show that cooling of the tropopause, as well as SSTs, impacts the intensity of tropical storms (Ramsay, 2013; Wang et al., 2014). In this respect, the recent cooling of the tropical tropopause and lower stratosphere from around 2000 (Randel 
et al., 2006; Randel and Jensen, 2013) should be investigated together with tropical tropospheric change.

The importance of the Pacific Decadal Oscillation (PDO) to decadal changes in global temperature and precipitation has been noted previously (Meehl et al., 2013; Dong and Dai, 2015; Trenberth, 2015). The most recent hiatus in global warming ended around 2013 followed by a strong warming due to an El Niño event in 2015 (Hu and Fedorov, 2017; Liu and Zhou, 2017; Urabe et al., 2017; Xie and Kosaka, 2017). However, the El Niño of 2015/16 differed from the large 1997/98 El Niño, which involved less warming in the eastern Pacific (Paek et al., 2017), conforming to a trend in increasing intensity of central Pacific-type El Niños (Kao and Yu, 2009; Johnson, 2013). In this sense, the anomalous tropical circulation from the mid-1990s to late 1990s did not terminate with the hiatus around 2013 but still persists today. Similarly, the northward shift of the convective zone in boreal summer continues, as shown below.

Multidecadal variations in the atmosphere-ocean coupled mode, such as the Atlantic Multidecadal Oscillation, have also been proposed as a cause of recent changes in the tropics (Wang et al., 2013; Kamae et al., 2017). Kamae et al. (2017) studied the impact of SSTs in various oceanic basins on recent trends in monsoon precipitation using a coupled ocean model. They were able to reproduce the recent increasing trend in monsoon rainfall in the Northern Hemisphere (NH), except for the Asian monsoon, with changes in Atlantic SST. Atlantic SSTs, however, have practically no effect on the African or Australian monsoons in the Southern Hemisphere (SH). Another difference from observations is that the simulated increase in rainfall occurs mainly over the oceans and at low latitudes between the Equator and $15^{\circ} \mathrm{N}$ rather than the observed increase over continents between around 10 and $20^{\circ} \mathrm{N}$ (see Fig. 3 of Kamae et al., 2017). Thus, it is difficult to attribute recent global trends to a regional mode of decadal oceanic variation alone. In this paper, we suggest that the fundamental cause of the recent decadal trend in the tropics from around 1999 is not the PDO but rather a strengthening of the deep ascending branch of the summertime Hadley circulation associated with a cooling in the lower stratosphere and a warming in the troposphere.

One of the components of the recent tropical circulation change is an expansion of the tropics (e.g., Davis and Rosenlof, 2012; Lucas et al., 2013; Hu et al., 2018; Byrne et al., 2018). Tropical expansion has been linked to changes in the descending branch of the Hadley cell in the subtropics (Kang and Polvani, 2011), but other potential mechanisms include changes in SST and in the vertical temperature structure of the troposphere, an overall increase in tropopause height, the internal variability in the climate system, and possibly stratospheric climate change (Seidel et al., 2007). Among the studies on tropical expansion those on the role of the tropical SST (Allen et al., 2014; Amaya et al., 2018) may be relevant to the present study. However, as will be shown later, a decadal ocean variability such as PDO may not be a fundamental factor which produces recent decadal trends in boreal summer. For the purposes of this paper we assume that the changes that we discuss are not directly related to those associated with tropical expansion.

Global climate change involves diverse aspects from the stratosphere to the ocean, from the polar region to the tropics, and from monsoons to severe storms. Each of these elements, as well as their relationships to each other and their roles in global climate change, should be investigated independently in great detail. Without the latter, we will be unable to see the "big picture". Stratospheric variation has generally been treated as a problem separate from recent surface climate change. The goal of this study is to provide a framework for assembling these diverse pieces of the climate-change puzzle by investigating the connection between the atmosphere and ocean in the tropics.

The remainder of this paper is organized as follows. The data used in this study are presented in Sect. 2, and the results of our analysis are given in Sect. 3. A summary and discussion of the causes of recent climate changes in the tropics are presented in Sect. 4.

\section{Data}

We use meteorological reanalysis data produced by the Japan Meteorological Agency (JMA), JRA-55 (Kobayashi et al., 2015). A large discontinuity was found at the end of the 1990s in a previous reanalysis product, JRA-25, when the TIROS Operational Vertical Sounder (TOVS) on board the National Oceanic and Atmospheric Administration (NOAA) satellite was switched to Advanced TOVS (ATOVS; Li et al., 2000). This discontinuity has largely been removed in the JRA-55 reanalysis (Kobayashi et al., 2015).

Outgoing longwave radiation (OLR) data provided by NOAA are widely used in analyses of convective activity in the tropics. In the present study, we use monthly mean OLR data $\left(1^{\circ} \times 1^{\circ}\right.$ latitude-longitude resolution) derived from the High-Resolution Infrared Radiation Sounder (HIRS) (Lee et al., 2007). An analysis of the precipitation is performed using Global Precipitation Climatology Project (GPCP) monthly mean data version 2.3 (Adler et al., 2003). Monthly mean gridded SST data from COBE with $1^{\circ} \times 1^{\circ}$ grid cells compiled by the JMA (Ishii et al., 2005) are used for the study of ocean surface change.

In the case of extreme deep convection, a strong updraft further penetrates beyond the level of neutral buoyancy and overshoots into the tropical tropopause layer (TTL). Such tropical overshooting clouds (COV) were identified using the diagnostics developed by Hong et al. (2005), which are based on brightness temperature differences measured by three high-frequency channels of the Advanced Microwave Sensing Unit (AMSU) module B or the Microwave Humidity Sensor (MHS). Data are from NOAA and MetOp satellites with periods of 2007-2013 for MetOp-A and 2014-2017 for 
MetOp-B. Their equatorial crossing times are nearly identical (see Fig. 1 of Funatsu et al., 2016). The original data calculated on a $0.25^{\circ} \times 0.25^{\circ}$ grid were resampled to a coarse one of $2.25^{\circ} \times 2.25^{\circ}$ grid for plotting. The number density of COVs is defined as the total number of COVs detected in each $2.25^{\circ} \times 2.25^{\circ}$ bin divided by the MetOp-MHS total pixel number to remove sampling bias, with units of parts per thousand.

The climatology is defined here as the 30-year mean from 1981 to 2010 . The exact starting dates of the recent decadal change are difficult to determine, on the one hand, due to the interannual variability (such as the El Niño events) and variable-dependent characteristics of change. For example, while some variables show a stepwise transition, others show a more gradual change. In the present study, we define the recent decadal change as the 1999-2016 mean anomalies from the 30-year (1981-2010) mean unless otherwise specified. By selecting the year 1999 as the starting year, we excluded the extremely large 1997/98 El Niño event from the recent period.

Seven El Niño events after 1979 are identified by the JMA based on 6-monthly mean SSTs in the Niño 3 sector $\left(5^{\circ} \mathrm{S}-5^{\circ} \mathrm{N}, 150-90^{\circ} \mathrm{W}\right.$; available at http://ds.data.jma.go.jp/ $\mathrm{gmd} / \mathrm{tcc} / \mathrm{tcc} / \mathrm{products} / \mathrm{elnino/ensoevents.html).} \mathrm{In} \mathrm{this} \mathrm{study,}$ we define the NH cold seasons of 1982/83, 1986/87, 1991/92, 1997/98, 2002/03, 2009/10, and 2015/16 as El Niño winters.

\section{Results}

\subsection{Recent decadal change}

The recent change of tropical convective activity is identified from the July-August-September (JAS) 1999-2016 mean anomalous OLR relative to the 30-year climatology (19812010; Fig. 1a). Increase in convective activity occurs over the African and Asian summer monsoon regions. Deep convective activity reaching the TTL in boreal summer is located primarily over the continents and their adjacent ocean north of $10^{\circ} \mathrm{N}$ (see, e.g., Fig. 2 in Liu and Zipser, 2005). It should be noted that the climatological mean streamlines around $15^{\circ} \mathrm{N}$ are connected to the stratosphere by crossing the tropopause $(100 \mathrm{hPa}$ ) in boreal summer (see, e.g., Fig. 3 of Seviour et al., 2012). In the present study, we call this part of the ascending branch of the Hadley circulation that penetrates the lower stratosphere the "deep ascending branch". Because the latitudinal location of the extreme deep convective zone is higher than that of the oceanic Intertropical Convergence Zone (ITCZ), enhancement of convective activity of this continental sector appears as a poleward shift in convective activity in the zonal-mean field (Fig. 1b): whereas the climatological OLR peaks around $10^{\circ} \mathrm{N}$, the anomalous OLR of the recent period has a maximum around $15^{\circ} \mathrm{N}$.

There is a close relationship between the location of the seasonally varying tropical convective active zone and cold tongues in the oceans. Convective activity shifts northward during boreal summer. Accordingly, cross-equatorial winds west of the American and African continents increase, which leads to a decrease in SSTs along coastal regions during boreal summer as a part of a seasonal cycle. The primary cause of cold tongues in tropical SSTs is the shape of the continents, the air-sea interaction, and the location of the rising branch of the Hadley circulation, as described by Xie and Philander (1994) and Xie (2004). We suggest in this paper that changes in the meridional circulation can similarly affect equatorial eastern Pacific SSTs by modulating the crossequatorial winds, as depicted in Fig. 2.

In order to investigate whether the northward shift in the convective zone is driven by the PDO, anomalous OLR during the two periods of neutral and negative phases of the PDO is shown in Fig. 1c and $d$ with anomalous SSTs during those periods (Fig. 1e and f). A characteristic horseshoe pattern in northern Pacific SST is evident during the negative phase of the PDO. Anomalous OLR indicates that convective activity is enhanced along $15-20^{\circ} \mathrm{N}$ irrespective of the phase of the PDO, except for the sector under the direct influence of the PDO in the eastern Pacific, where cooling is greater during the negative phase. However, even during the neutral phase of the PDO, negative anomalies in SST exist in the tropics west of South America. This suggests that SST cooling west of South America is not driven solely by the PDO but is related to stronger cross-equatorial winds that we hypothesize are connected to an enhanced convective activity over the African-Asian sector.

The atmospheric circulation and SST changes associated with the convective activity are depicted in Fig. 2. The spatial structure of the recent decadal trend varies with the season. The top panels show the 1999-2016 mean anomalous OLR during (a) JAS and (b) October, November, and December (OND). Because the response of SST follows the atmospheric circulation, anomalous SSTs during the following month (i.e., August, September, and October, ASO, and November, December, and January, NDJ) are displayed in Fig. 2c and d. During JAS, the anomalous cross-equatorial flow west of South America intensifies following a poleward shift in convectively active regions. The cross-equatorial flow changes from westward to eastward when it crosses the Equator, following the change in sign of the Coriolis force. This results in a strengthening of the climatological easterlies in the $\mathrm{SH}$ and enhances anomalous convergence near New Guinea. In contrast, easterlies are weakened in the $\mathrm{NH}$, which explains the warming (cooling) north (south) of the Equator. Such a meridional seesaw of anomalous SSTs and cross-equatorial flow suggests an important role for wind-evaporation-SST (WES) feedback (Xie and Philander, 1994) in recent trends. The center of anomalous negative OLR moves to the equatorial eastern Indian Ocean from boreal summer to autumn, which results in a strengthening of anomalous easterlies over the equatorial central Pacific and a westward extension of low SSTs over the Equator. 
(a)

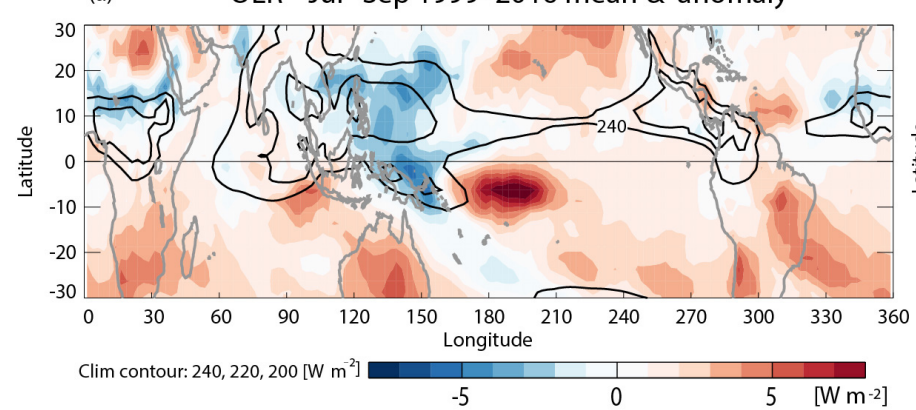

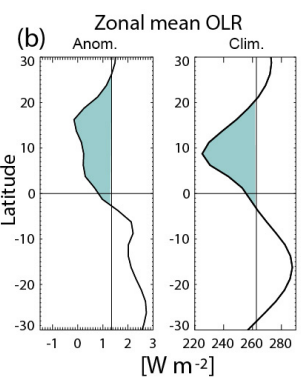

\section{Jul-Sep mean OLR}
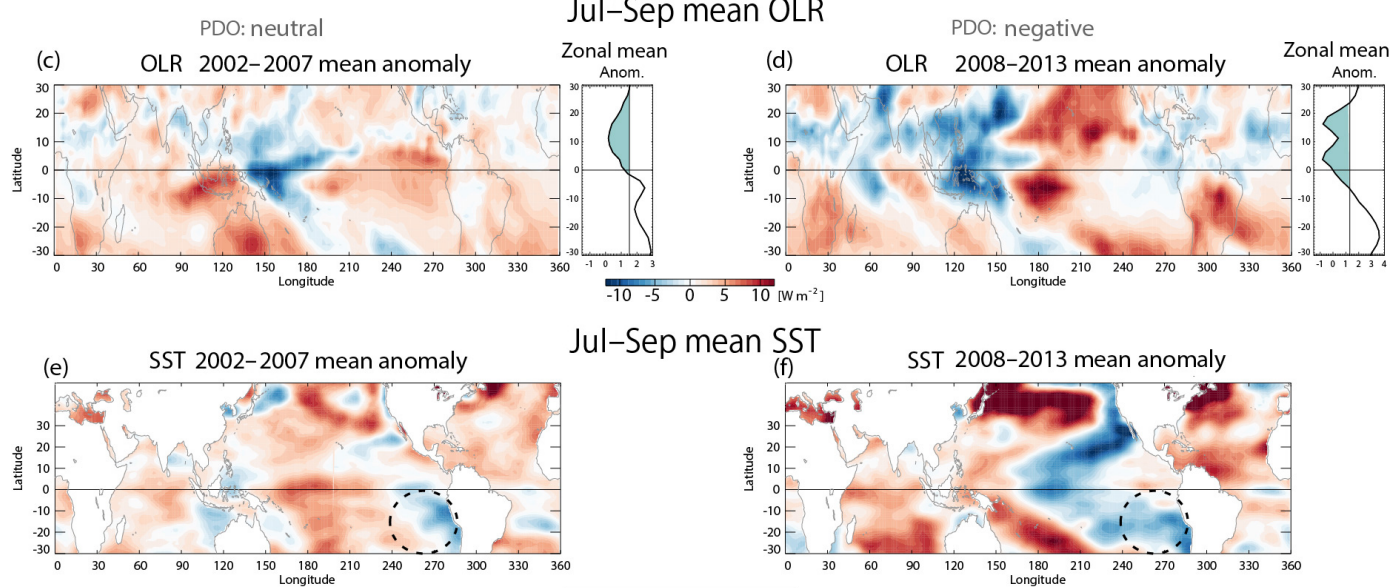

Jul-Sep mean SST

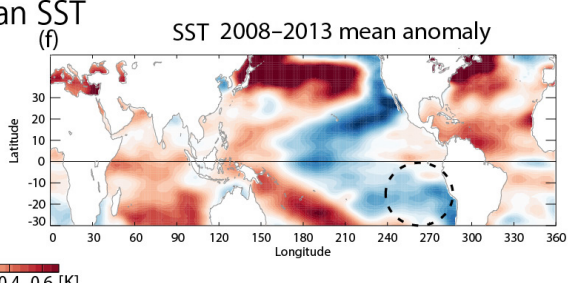

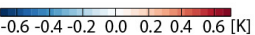

Figure 1. (a) Climatological (1981-2010) JAS mean OLR (contours: 240, 220, and $200 \mathrm{~W} \mathrm{~m}^{-2}$ ) and anomalous JAS OLR (departures from climatology) during 1999-2016 (color shading); (b) zonal-mean profiles of (a): anomalies from climatology (left) and climatology (right); (c) anomalous OLR as in (a) and (b, left) but for 2002-2007; (d) anomalous OLR as in (a) and (b, left) but for 2008-2013, and anomalous July-September SST (departures from climatology) for (e) 2002-2007 and (f) 2008-2013.
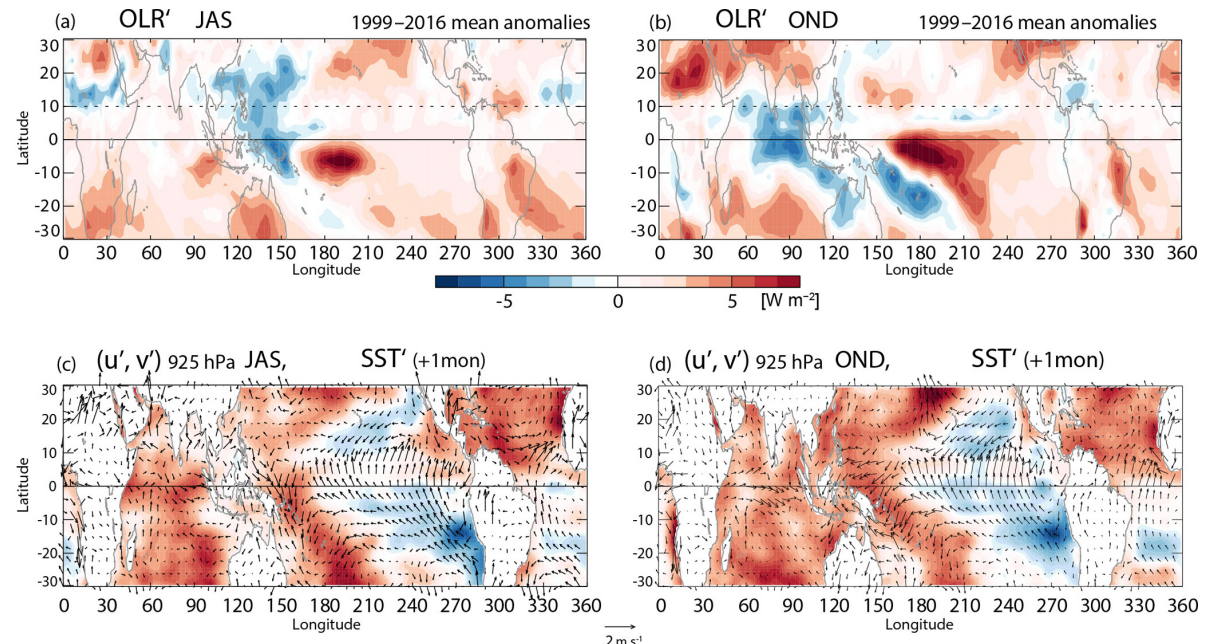
$2 \mathrm{~m}$

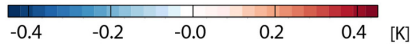

Figure 2. (a) JAS and (b) OND mean anomalous OLR for 1999-2016; (c) JAS and (d) OND mean anomalous horizontal winds at $925 \mathrm{hPa}$ (arrows) for 1999-2016 superimposed on anomalous SSTs (color shading) with a 1-month lag (i.e., ASO and NDJ, respectively). 


\subsection{Ascending branch of the Hadley circulation}

The Hadley circulation is usually represented by a pair of thermally direct cells, symmetric about the Equator, with rising motion over the equatorial belt and sinking motion over the subtropics, with noticeable seasonal variability (e.g., Dima and Wallace, 2003). The mean meridional circulation driven by extreme deep convection further penetrates up to the tropical tropopause (Liu and Zipser, 2005). Here we first investigate the different modes of variability in mean meridional circulation and their relationship with Hadley cells during the boreal summer, focusing on the vertical structure including the lower stratosphere.

Because large detrainment occurs from deep convective clouds near the cloud top, a combination of the vertical velocity and horizontal divergence may indicate large-scale circulation related with deep convective activity. Therefore, a singular value decomposition (SVD) analysis (Kuroda, 1998) was conducted using the normalized covariance matrix between zonal-mean pressure vertical velocity $(\omega)$ and horizontal air divergence for July-August-September (JAS) 19792016. The value at each grid point was weighted by the vertical-layer thickness and the cosine of the latitude in the meridional direction. The SVD calculations were performed from 700 to $30 \mathrm{hPa}$ levels, but to obtain a general view of the entire troposphere the heterogeneous correlation was extended down to $1000 \mathrm{hPa}$. Results for the three SVD leading modes are presented in Fig. 3.

Figure $3 \mathrm{a}$ shows that the centers of actions in the divergence field are located in the upper troposphere around $200 \mathrm{hPa}$ for SVD 1 and 3, whereas in the case of SVD 2 it is located around the tropopause at $100 \mathrm{hPa}$. Accordingly, the vertical velocity fields of SVD 1 and 3 are confined within the troposphere, but that of SVD 2 is extended from the TTL to the lower stratosphere. It is also noticeable that SVD 1 and 3 show a similar structure of a meridional seesaw in divergence and vertical velocity fields, except that the horizontal scale of SVD 3 is about half of SVD 1.

The mass stream function of the climatological residual mean meridional circulation (Kobayashi and Iwasaki, 2016) was examined (Fig. 3a) in order to investigate the correspondence between the climatological Hadley circulation. For convenience, streamlines related to the closed cells in the troposphere, and those extending to the stratosphere (i.e., deep ascending branch), are displayed separately. The results suggest that SVD 1 and 3 represent changes in the strength and meridional shift of the rising branch of Hadley cells. For SVD 2, however, the picture is different: negative values of vertical velocity field in SVD 2 are located along the climatological streamlines connected to the stratosphere, suggesting a strengthening of vertical velocity around the climatological deep ascending branch of the Hadley cell. The different nature of SVD 2 from that of SVD 1 and 3 is also apparent in their time coefficients: an increasing trend is prominent for SVD 2, while for SVD 1 and 3 there is large year- to-year variation. In addition, the amplitude of the interannual variation in the time series of SVD 1 and 3 shows a decadal change. In the case of SVD 1, negative values became smaller from the beginning of the 2000s, whereas in the case of SVD 3 negative values become larger from the end of the 1990s. This almost simultaneous change in the amplitude and a similarity in spatial structure suggest the possibility that a decadal variation in the spatial structure of the same phenomenon is represented by two SVD modes.

Correlation coefficients between the time coefficients of the divergence component of each SVD mode and the OLR, divergence at $925 \mathrm{hPa}$, and surface $(2 \mathrm{~m})$ air temperature are shown in Fig. 4. (For easier comparison correlation with SVD 1 time coefficients are displayed above those of SVD 3.) SVD 2 has quite different characteristics compared to SVD 1 and 3: reinforced negative OLR (that is, of convective activity) does not coincide with the region of higher surface temperature as in SVD 1 and 3. Surface temperature does not change or even decrease in some part over the African-Asian continental sector. It is also noted that the enhanced convective zone over the continental sector shows little relationship with the convergence near the surface. SVD 1 is easily identified as a phenomenon related to the El NiñoSouthern Oscillation (ENSO) with large amplitude in the surface temperature and OLR over the equatorial eastern Pacific. This is in agreement with results from the times series shown in Fig. 3c for SVD 1, which shows that peaks in the time series coincide with the occurrence of the El Niño (dots). Surface temperature and divergence maps of SVD 3 show a meridional seesaw in the tropical northeastern Pacific. Such a pattern suggests that SVD 3 is related with the Pacific meridional mode (PMM) (Chiang and Vimont, 2004) or the central Pacific ENSO (Stuecker, 2018). The above results support the rationale that the decadal evolution of ENSO-related variation is represented by two SVD modes 1 and 3 .

The present analysis suggests that the variability in the deep ascending zone represented by SVD 2 is a linearly independent mode from that related to the oceanic ITCZ, represented by SVD 1 and 3. However, the climate system is highly nonlinear. Therefore, changes in the deep ascending branch of the Hadley circulation such as those represented in SVD2 could modulate the ITCZ over the oceanic sector through induced changes in cross-equatorial winds as suggested in Fig. 2.

\subsection{Variations over continents and oceans}

In the analysis above, two different features of decadal variability are evident, over oceanic and continental sectors. According to our hypothesis the former corresponds to the variability in oceanic ITCZ constituting the main ascending branch of the Hadley cells, and the latter is related to the deep ascending branches of the Hadley circulation connected to the stratosphere. Here we examine variations over the African continental $\left(10^{\circ} \mathrm{W}-40^{\circ} \mathrm{E}\right)$ and Pacific Ocean (170 

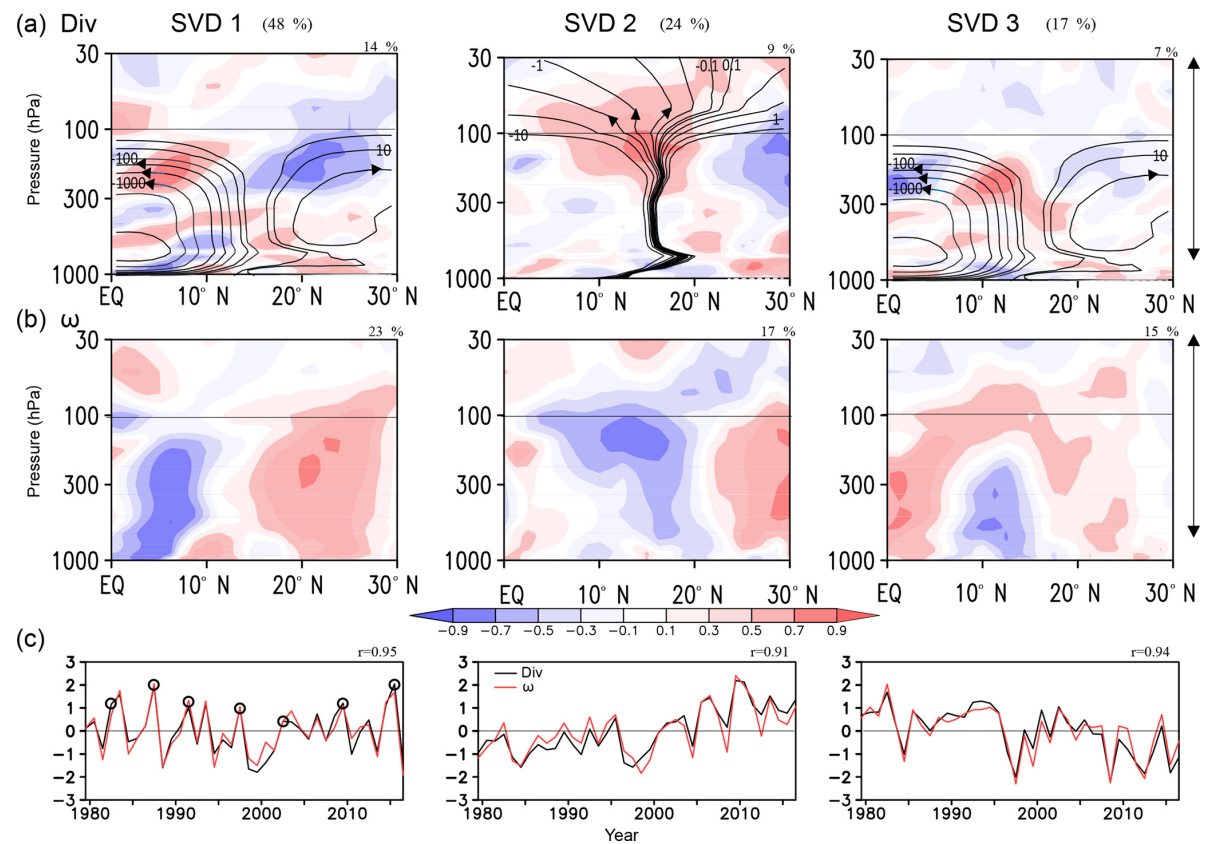

Figure 3. Singular value decomposition analysis of the zonal-mean anomalous horizontal divergence and anomalous pressure vertical velocity in the tropics (Equator-30 ${ }^{\circ} \mathrm{N}$ ) during JAS from 1979 to 2016: from left to right, SVD 1, SVD 2, and SVD 3. (a) Heterogeneous correlation map of horizontal divergence. (b) Same as (a), except for the pressure vertical velocity map. (c) Time coefficients (black: divergence; red: pressure vertical velocity). Right-hand-side arrows indicate the levels used in the SVD calculations. Streamlines in (a) indicate mass stream function of the climatological residual mean meridional circulation (streamlines are plotted with logarithmic scaling: $\left.\pm 0.1,0.2,0.5,1,2,5,10,20,50,100 \ldots \times 10^{10} \mathrm{~kg} \mathrm{~s}^{-1}\right)$. Open circles in (c) indicate an El Niño event.

$120^{\circ} \mathrm{W}$ ) sectors to reveal the most prominent characteristics in each region. The climatological annual cycle in zonalmean pressure vertical velocity at $300 \mathrm{hPa}$ for each region is depicted in Figs. 5a and 6a. A region of enhanced convective activity migrates north and south over the African continent following the seasonal variation in solar heating (Fig. 5a). It should be noted that the evolution of the convective zone includes a jump during the summer monsoon season (Hagos and Cook, 2007). Over the Pacific Ocean, the convective zone shows only a small latitudinal displacement and is located in the NH near 5-10 $\mathrm{N}$ throughout the year (Fig. 6a). Latitude-time cross sections of the 3-monthly mean anomalous (departures from the 1981-2010 climatology) $300 \mathrm{hPa}$ vertical velocities are shown for February 1979 to November 2016 over the African sector in Fig. 5b. The vertical velocity increases from the mid-1990s in both hemispheres around $10-20^{\circ}$ in latitude, which according to our hypothesis corresponds to the location of the deep ascending branch in summertime Hadley circulation. Accordingly, the annual mean precipitation over Africa has increased during the recent period (1999-2016) in both hemispheres over the Sahel and Namibia (Fig. 5c).

Over the Pacific Ocean sector (Fig. 6b), strong upward motion appears over the Equator when El Niño events occur. This has been identified as an effect of the ENSO on the ITCZ (Waliser and Gautier, 1993). The anomalous re- gion of upward motion, however, tends to remain north of the Equator after 1999. Accordingly, the annual mean anomalous precipitation during the recent period shows a large increase near $5-10^{\circ} \mathrm{N}$, the mean position of the ITCZ over the ocean, but decreases over the Equator and the SH (Fig. 6c). This manifests as a narrowing and intensification of the ITCZ in recent decades, with little change in its latitudinal position (Lucas et al., 2013; Wodzicki and Rapp, 2016). The change over the ocean sector is related to the varying strength of the cross-equatorial winds (Fig. 6d). After 1999, although SSTs increased over the Equator during El Niño events, anomalous northward winds remained strong and convective activity tended to remain in the $\mathrm{NH}$.

Figure 6e shows the longitude-time section of the anomalous OLR over the equatorial SH $\left(0-10^{\circ} \mathrm{S}\right)$. The effects of cooling of the eastern equatorial Pacific in the SH can also be seen in structural changes in El Niño-Southern Oscillation (ENSO) phenomena after 1999. Convective activity greatly increases over the Pacific during El Niño events before 1999. However, after 1999, Pacific convective activity is suppressed and an increase in convective activity during El Niño is apparent only over the central Pacific. In contrast, convective activity west of $160^{\circ} \mathrm{E}$ over the Maritime Continent generally increases after 1999. Such changes are likely related to a decadal change in anomalous zonal winds over the tropical $\mathrm{SH}\left(10^{\circ} \mathrm{S}-5^{\circ} \mathrm{N}\right.$; Fig. $\left.6 \mathrm{f}\right)$, which in turn is 
(a) OLR
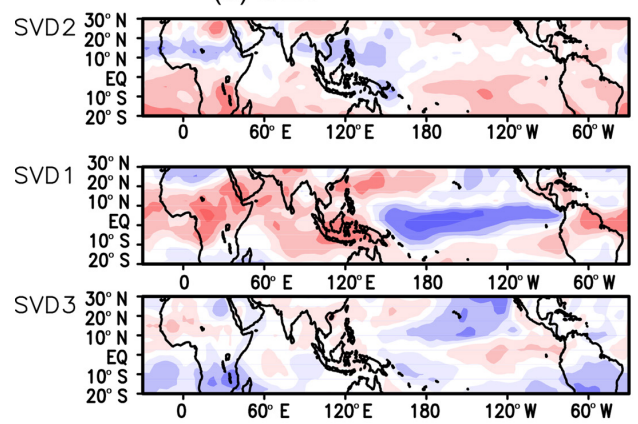

(c) Ts
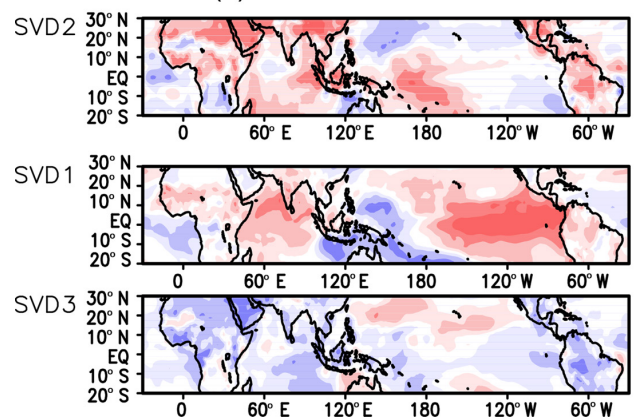

(b) Div. 925
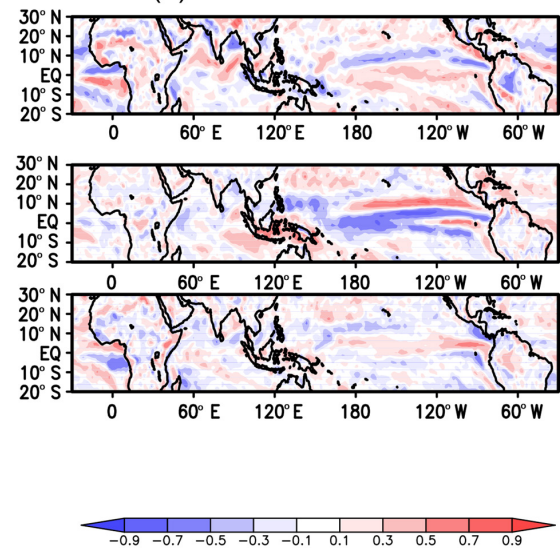

Figure 4. Correlation coefficient between time series of divergence component of each SVD mode and (a) OLR, (b) horizontal divergence at $925 \mathrm{hPa}$, and (c) surface temperature, at each grid. Each panel in (a, b, c) shows a correlation map of SVD 2, SVD 1, and SVD 3, from top to bottom.

(a) Clim:w $300 \mathrm{hPa}$

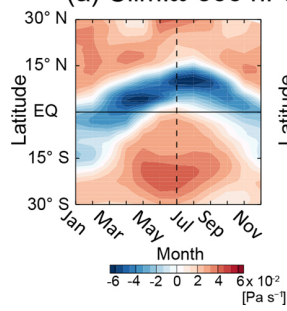

(b) $\omega^{\prime} 300 \mathrm{hPa}$

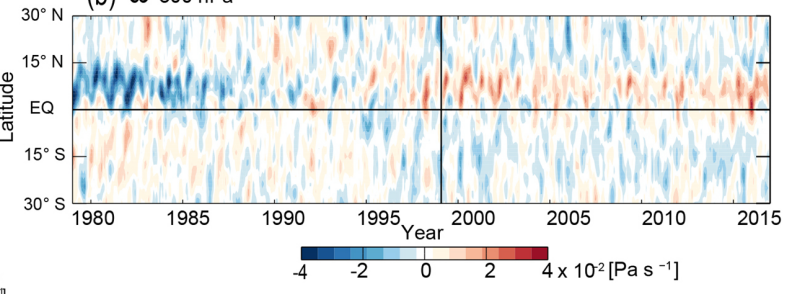

(1999-2016) (c) Precip. anom.

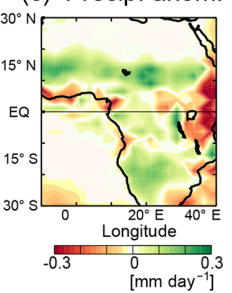

Figure 5. (a) Latitude-time section of the climatological zonal-mean pressure vertical velocity at $300 \mathrm{hPa}$ averaged over the African sector $\left(10^{\circ} \mathrm{W}-40^{\circ} \mathrm{E}\right)$, (b) latitude-time section of monthly mean anomalous pressure vertical velocity from February 1979 to November 2016 , and (c) latitude-longitude map of annual mean anomalous precipitation during 1999-2016 over the African sector. A 3-month running mean is applied in (b).

connected to increased cross-equatorial southerlies through Coriolis-force effects. Latitude-time sections of 3-monthly anomalous SSTs in the Niño 3.4 sector (Fig. $6 \mathrm{~g}$ ) indicate little change in latitudinal structure; thus changes in spatial structure related to the ENSO around 1999 support our interpretation of the relationship between SVD 1 and 3 above.

We next take a closer look into tropospheric vertical velocity variations. The tropospheric zonal-mean vertical velocity has a relatively weak connection with the horizontal distribution of OLR possibly because regional-scale variations dominate in the lower troposphere due to surface topography.
Therefore, meridional sections of standardized mean JAS 1999-2016 anomalous pressure vertical velocity were calculated for several sectors instead of zonal means (Fig. 7). The top panel in Fig. 7a shows the anomalous zonal-mean field (shaded), which is comparable to that extracted by SVD 2 in Fig. 3b, along with contours indicating the 30-year climatology for reference. The middle panels are the same as the top panel but divided into two parts: (b) an AfricanAsian continental sector $\left(30^{\circ} \mathrm{W}-130^{\circ} \mathrm{E}\right)$ and (c) a PacificAtlantic oceanic sector $\left(130-330^{\circ} \mathrm{E}\right)$. A strengthening of upward velocity in the TTL and lower stratosphere occurs in 


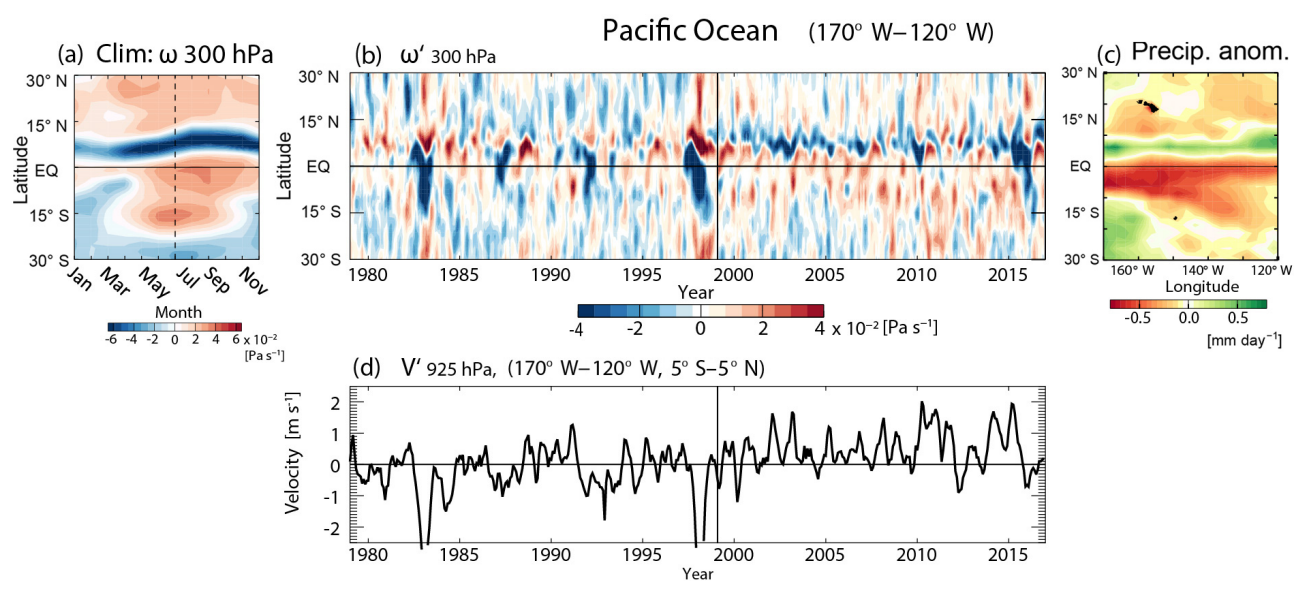

(e) $\mathrm{OLR}^{\prime}\left(0^{\circ}-10^{\circ} \mathrm{S}\right)$
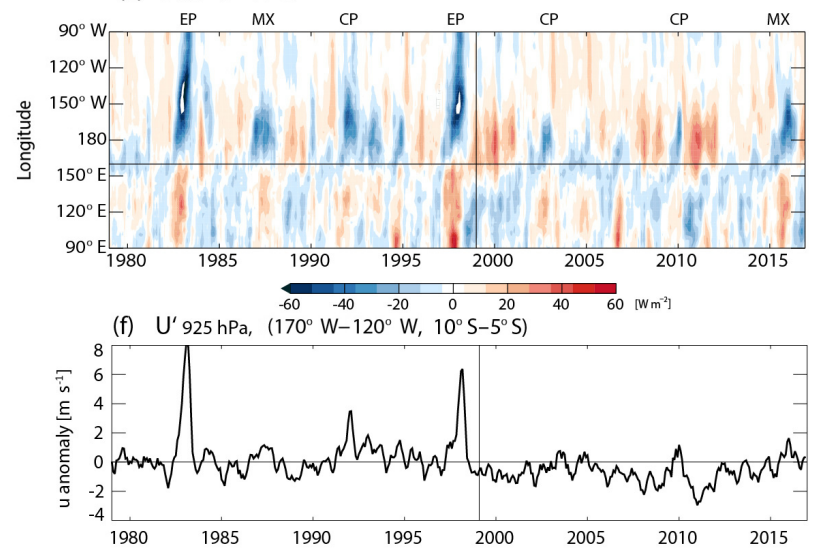

(g) $\mathrm{SST}^{\prime}\left(170^{\circ} \mathrm{W}-120^{\circ} \mathrm{W}\right)$

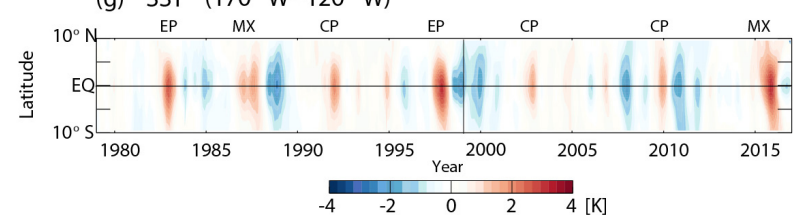

Figure 6. (a-c) Same as Fig. 5 but for the eastern Pacific Niño $3.4\left(170-120^{\circ} \mathrm{W}\right)$ sector; (d) monthly mean anomalous meridional wind component around the Equator $\left(5^{\circ} \mathrm{S}-5^{\circ} \mathrm{N}\right.$ ) over the Niño 3.4 sector; (e) similar to (a) but for the time-longitude section of OLR around the Equator $\left(5^{\circ} \mathrm{S}-5^{\circ} \mathrm{N}\right)$ over the Indian Ocean-Pacific sector; (f) same as (d) but for the zonal wind component in the tropical $\mathrm{SH}\left(10-5^{\circ} \mathrm{S}\right)$; (g) monthly mean anomalous SST over the Niño 3.4 sector. Eastern Pacific (EP), central Pacific (CP), and mixed-type (MX) El Niño events are indicated (Paek et al., 2017).

the continental sector, together with a northward shift in the troposphere, whereas in the oceanic sector a strengthening in vertical velocity occurs around $5-10^{\circ} \mathrm{N}$ without a latitudinal shift. If we limit the continental sector to the African continent $\left(20^{\circ} \mathrm{W}-20^{\circ} \mathrm{E}\right)$ to exclude the influence of the Indian Ocean, the abovementioned continental characteristics become even clearer (Fig. 7d). Over the oceanic sector, an increase in vertical velocity occurs around $7.5^{\circ} \mathrm{N}$ (Fig. 7f), but in the western Pacific sector $\left(130-170^{\circ} \mathrm{E}\right)$ the upward velocity develops primarily south of the Equator $\left(0-10^{\circ} \mathrm{S}\right.$; Fig. 7e). We also note that the climatological vertical velocity in the western Pacific sector is essentially confined to the lower troposphere over the equatorial SH $\left(10-0^{\circ} \mathrm{S}\right)$. This ob- servation can be attributed to the fact that convergence occurs over the warm ocean east of New Guinea (Fig. 2c). This result indicates that despite a variety of profiles among the sectors, the zonal-mean vertical field in the TTL primarily follows variations over the African-Asian continental sector.

\subsection{Stratosphere-troposphere coupling}

Continuity in a zonally averaged field does not necessarily mean actual continuity at each location, as is evident from the above analysis. To investigate continuity within the deep ascending branch of the Hadley circulation from the upper troposphere to the stratosphere in more detail, longitudeheight sections of the normalized anomalous pressure ver- 
Standardized JAS 1999-2016 mean $\omega$

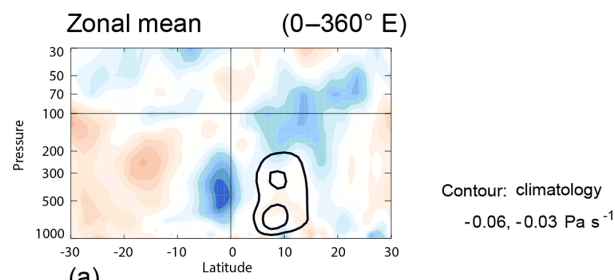

(a)

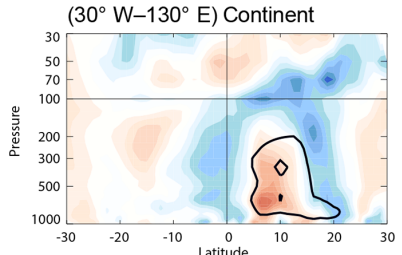

(b)

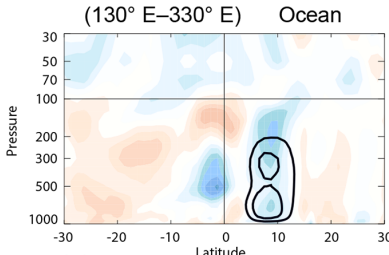

(c)

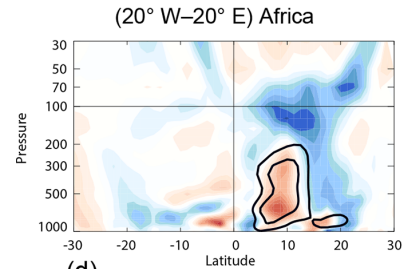

(d)

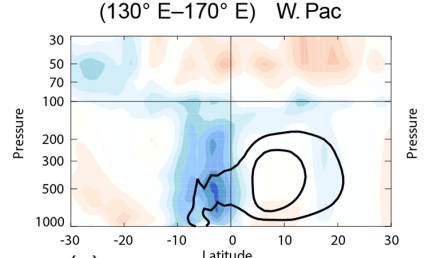

(e)

$$
-2.0
$$

Figure 7. (a) Standardized anomalous pressure vertical velocity (departures from 1981-2010 climatology) - the climatological JAS mean zonal-mean pressure vertical velocity is indicated by contours ( -0.06 and $\left.-0.03 \mathrm{~Pa} \mathrm{~s}^{-1}\right)$; (middle panels) same as (a) but for (b) the AfricanAsian continental sector $\left(30^{\circ} \mathrm{W}-130^{\circ} \mathrm{E}\right)$ and (c) the Pacific-Atlantic oceanic sector $\left(130-330^{\circ} \mathrm{E}\right)$; (bottom panels) same as (a) but for (d) the African continental sector $\left(20^{\circ} \mathrm{W}-20^{\circ} \mathrm{E}\right)$, (e) the western Pacific sector $\left(130-170^{\circ} \mathrm{E}\right)$, and (f) the central Pacific-Atlantic sector $\left(170-330^{\circ} \mathrm{E}\right)$.

tical velocities averaged over latitudes of $10-20^{\circ}$ in the summer hemisphere are displayed in the top panels of Fig. 8a and $b$. The bottom panels show the distributions of climatological (2007-2017) COV occurrence frequency in the same latitudinal zone. If a normal distribution is assumed, absolute values of 17-year mean standardized anomalies that are larger than 0.5 are statistically different from 0 at the $95 \%$ confidence level. An increasing trend in upwelling occurs over the continental sector, particularly where COVs are frequent. These characteristics are commonly seen in both summer hemispheres. The contrast between the continental and oceanic sectors is clearer in the SH (Fig. 8b) where the distribution of land is simpler. Because COV occurs in deep convective clouds penetrating into the TTL beyond the level of neutral buoyancy, such increased vertical velocity in the TTL over the region of frequent COV seems reasonable. It should also be noted that a connection between COV and vertical velocity in the tropical lower stratosphere on a daily scale has been identified in previous studies (Eguchi et al., 2015; Kodera et al., 2015).

To investigate stratosphere-related variations in the troposphere, the JAS mean pressure vertical velocity $(\omega)$ at
$30 \mathrm{hPa}$ averaged over the tropical $\mathrm{SH}\left(0-25^{\circ} \mathrm{S}\right)$ is chosen as the index of stratospheric mean meridional circulation $\left(I_{\omega}\right.$; Fig. 9a). The correlation coefficient between $I_{\omega}$ and zonalmean $\omega$ at each grid point (Fig. 9b) shows a correlation pattern similar to the SVD 2 in Fig. 1. To highlight the relationship between the interannual variation and climatology, the stream function from Fig. 3 is displayed as contours in Fig. $9 \mathrm{~b}$ and c. It is clearly seen that the variation in stratospheric upwelling (Brewer-Dobson circulation) is connected to the upwelling of the deep ascending branch of the Hadley circulation, similar to that in climatology.

The correlation between $I_{\omega}$ and zonal-mean temperature at each grid point from $90^{\circ} \mathrm{S}$ to $90^{\circ} \mathrm{N}$ is shown in Fig. 9c. Tropical upwelling is not only related to cooling in the tropics and the summer hemisphere but to warming in the downwelling region around the winter polar stratosphere. This suggests the dynamic nature of recent tropical stratospheric cooling. Stratospheric upwelling is also connected with convective activity along $15-20^{\circ} \mathrm{N}$ (Fig. 9d), as discussed above. Correlation coefficients between $I_{\omega}$ and $925 \mathrm{hPa}$ zonal and meridional winds at each grid point are shown as arrows in Fig. 9e. An increase in cross-equatorial winds in the eastern Pacific 
(a) Jul-Sep $\left(10^{\circ} \mathrm{N}-20^{\circ} \mathrm{N}\right)$

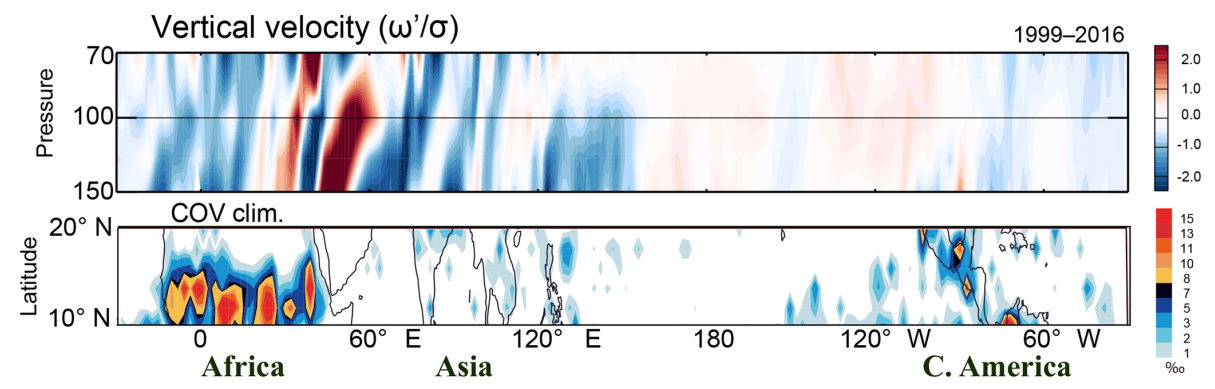

(b) Dec-Feb $\left(10^{\circ} \mathrm{S}-20^{\circ} \mathrm{S}\right)$

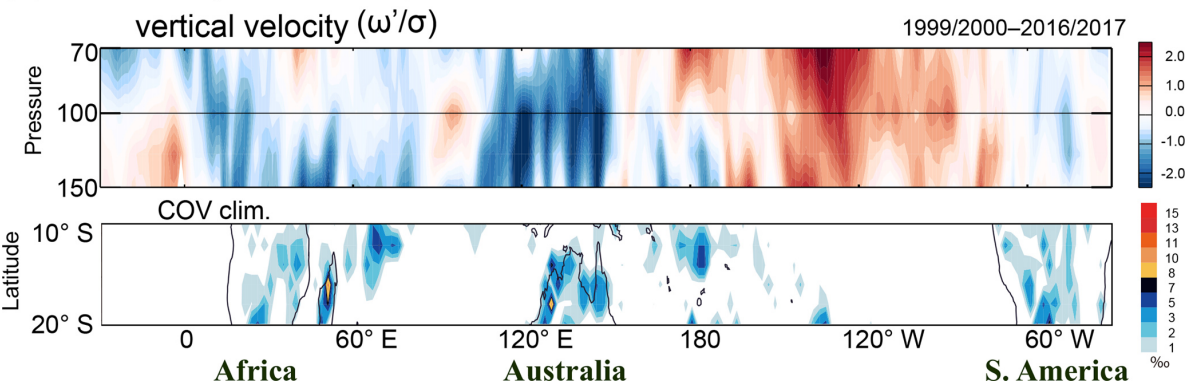

Figure 8. (a) (top) Height-longitude section of the standardized (with respect to the interannual variation) anomalous pressure vertical velocity averaged over 10-20 $\mathrm{N}$ during boreal summer (JAS) 1999-2016; (bottom) climatological (2007-2017) occurrence frequency of convective overshooting (COV) in the same latitudinal zone (units of parts per thousand); (b) as in (a) but for 10-20 $\mathrm{S}$ during austral summer (DJF).

and Atlantic is observed. The impact of near-surface wind variations on SST can be seen in the lagged correlation with SST in Fig. 9e. Cooling in the equatorial eastern Pacific is largest with a time lag of 5 months (i.e., during December, January, and February, DJF), consistent with the development of La Niña-like SSTs during boreal autumn (Fig. 2).

On the basis of the results presented in the previous sections we suggest the mechanism depicted in Fig. 10. (a) Cooling of the lower stratosphere occurred due to the direct radiative effect and dynamic effect of the stratospheric mean meridional circulation. (b) A decrease in the lower stratospheric temperature produced favorable conditions for the development of extreme deep convection. A stratospheric cooling effect is felt by convections reaching the TTL, primarily over the continental sector. (c) An enhancement of the extreme deep convection off-equatorial region produces stronger cross-equatorial flow near the surface. (d) Strengthening of surface winds cools the ocean through increased evaporation.

Accordingly, we selected four variables that can be considered fundamental to the recent tropical trends: (a) tropical lower stratospheric temperatures in early summer (temperature at $70 \mathrm{hPa}$ averaged over $20^{\circ} \mathrm{S}-20^{\circ} \mathrm{N}$ at the bottom of the TTL from 16 July to 16 August), (b) pressure vertical velocity at the bottom of the TTL ( $150 \mathrm{hPa})$ in August, (c) AugustOctober mean southward winds south of the Equator (0$\left.10^{\circ} \mathrm{S}\right)$ in the western hemisphere $\left(0-180^{\circ} \mathrm{W}\right)$, and $(\mathrm{d})$ time tendency of SST from early summer (May-July) to late autumn (October-December) in the tropical Pacific west of the South American continent $\left(15-5^{\circ} \mathrm{S}, 100-80^{\circ} \mathrm{W}\right)$. Time series of these four variables (a-d) are displayed in Fig. 10 (right). When all four variables are negative (red dots), we define this as a negative event. Similarly, when all variables are positive (black dots), it is defined as a positive event. All six positive events occurred within the first 14 years, whereas all seven negative events occurred during the last 13 years. A chi-squared test was conducted to examine whether such distributions of events can occur by chance, by dividing the whole 39 years into three equal 13 -year periods. The result $\left(\chi^{2}=23\right)$ indicates that the probability of such distributions occurring by chance is less than $0.1 \%$. Therefore, there is a statistically significant trend towards negative events in recent decades.

However, the key question here is whether there is a causal relationship among the variables. We introduced a seasonal variation in the selection of the variable from the period of stratospheric cooling at the end of July and to the cooling of the ocean from summer to autumn; that is, change in Pacific SST occurred following a change in cross-equatorial winds, increased upwelling in the TTL, and stratospheric cooling in early summer. This time evolution tentatively suggests a causality among the variables. 
(a)
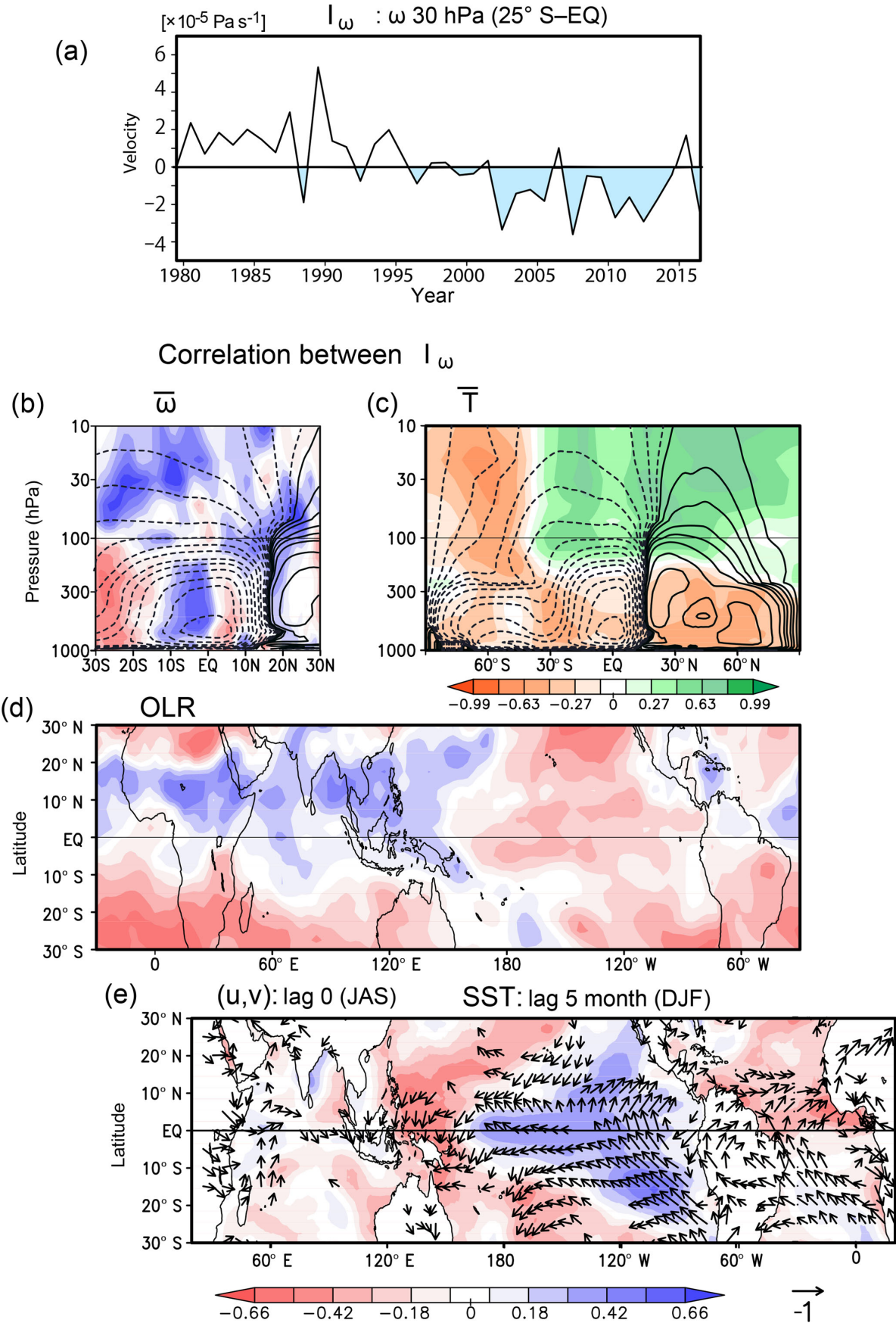

Figure 9. (a) Time series of JAS mean pressure vertical velocity $(\omega)$ at $30 \mathrm{hPa}$ averaged over $0-25^{\circ} \mathrm{S}$ as an index for tropical stratospheric vertical velocity $\left(I_{\omega}\right)$; correlation coefficients between $I_{\omega}$ and (b) zonal-mean $\omega$, (c) zonal-mean temperature $T$ at each grid, (d) OLR, and (e) horizontal winds at $925 \mathrm{hPa}$ (arrows). A lagged correlation with DJF mean SST is also presented by color shading in (e). Contours in (b, c) indicate the climatological residual mean meridional circulation in JAS. Solid and dashed lines indicate clockwise and counterclockwise directions, respectively.

\section{Summary and discussion}

Convective activity around the deep ascending branch of the boreal summer Hadley circulation (Fig. 3, SVD 2) shows an increasing trend over the continental sector (Fig. 4). In con- trast, over the oceanic sector the decadal change manifested as changes in the spatial structure of the ENSO-related phenomenon (Fig. 4, SVD 1). It is suggested that the observed 1999-2016 decadal SST cooling in the eastern Pacific is related to an increase in cross-equatorial winds and easterlies in 

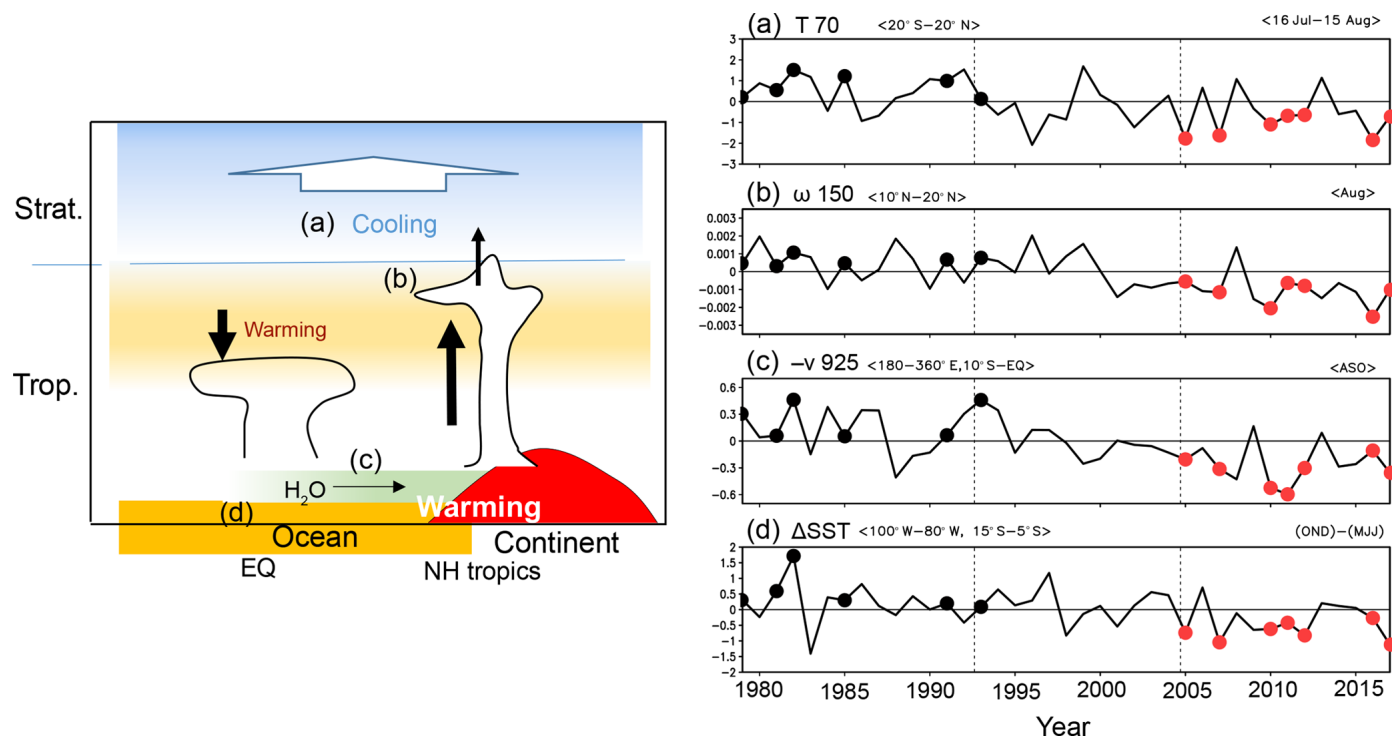

Figure 10. On the left is a schematic of recent changes in the tropics (see text), in which the labels (a-d) indicate the location of the variable shown in the right panels; (right) time series of four key variables as departures from the climatology: (a) lower stratospheric temperature, (b) upwelling in the TTL, (c) cross-equatorial near-surface winds, and (d) time tendency of SST from summer to autumn. Black and red dots indicate years when the four variables are of the same polarity (positive and negative, respectively).

the tropical SH, which are themselves related to a strengthening of convective activity around the climatological deep ascending branch of the Hadley circulation during boreal summer over the African-Asian sector (Fig. 2). In addition, a correlation analysis (Fig. 9) indicates that these variations in convective activity and SST are related to vertical velocity near the tropopause. The relationship between convective activity and cooling of the tropical eastern Pacific can be explained through changes in cross-equatorial winds involved in a wind-evaporation-SST (WES) feedback (Xie, 2004). Accordingly, a combination of these two processes can be used as a working hypothesis for the recent tropical changes, as shown in Fig. 10.

It is difficult to statistically demonstrate a causal relationship among variables having large trends, such as (a) lower stratospheric temperature, (b) upwelling in the TTL, (c) cross-equatorial near-surface winds, and (d) time tendency of SST from boreal summer to autumn. Nevertheless, time lags introduced in selected variables from summer to autumn suggest that the above processes are related, as shown schematically in the left panel of Fig. 10. Current global models have difficulty accurately simulating the effect of extreme deep convection on the TTL. Suitably designed numerical experiments using global models with improved convective parameterizations will be needed to add further support to these ideas.

Although their period of observation may be too short (10 years of Atmospheric Infrared Sounder data), Aumann and Ruzmaikin (2013) reported that tropical deep convection over land shows an increasing trend, whereas that over oceans shows a decreasing trend. Furthermore, Taylor et al. (2017) showed that intense mesoscale convective systems in which cloud-top temperatures were lower than $-70^{\circ} \mathrm{C}$ have largely increased over the Sahel since 1982. A temperature of $-70^{\circ} \mathrm{C}$ corresponds to the air temperature at $\sim 150 \mathrm{hPa}$. This means that extreme deep convection penetrating into the TTL largely increased over the African continent, consistent with the analysis presented here.

In the present study, a poleward shift in the convective zone corresponds to enhanced convective activity in the deep ascending branch in the summertime Hadley circulation, located at a higher latitude (around $15^{\circ} \mathrm{N}$ ) than the main ascending branch over the ocean (around $7.5^{\circ} \mathrm{N}$ ). For the purposes of this paper we assume that the changes that we discuss are independent from those associated with tropical expansion. This paper is based on the hypothesis that recent increase in the convective activity in the deep branch of the Hadley circulation over the continental sector can be considered independent of the shift in the ITCZ studied by many other authors such as Schneider (2017) and Byrne et al. (2018), who are primarily relevant to the oceanic sector.

The increasing trend in Earth's surface temperature is generally attributed to an increase in greenhouse gases, such as $\mathrm{CO}_{2}$ (IPCC, 2013). Such a change in radiative forcing may explain the global characteristics of recent changes. The effect of increased $\mathrm{CO}_{2}$ can be divided into a direct radiative effect and an indirect effect through changes in SST. Model experiments have shown that the direct radiative effect of $\mathrm{CO}_{2}$ increases tropical upward motion, particularly over the Sahelian sector, whereas it suppresses upwelling over the oceanic sector in the Pacific (see Fig. 8 of Gaetani et al., 2016). An increase in $\mathrm{CO}_{2}$ raises the Earth's surface temperature but 
decreases stratospheric temperatures. Note, however, that recent cooling in the lower stratosphere-tropopause region is also due to a dynamic effect (Abalos et al., 2015). Further investigation is needed to determine whether the stratosphere is merely passively responding to or playing an active role in tropospheric circulation change. Here we emphasized that stratospheric change should be considered together with tropospheric change.

Data availability. Datasets used in this paper are all publicly available. Meteorological reanalysis datasets created by JMA (JRA-55) are available from http://search.diasjp.net/en/dataset/ JRA55 (Kobayshi et al., 2015; last access: 15 February 2019). The COBE monthly mean SST dataset can be obtained from the JMA website http://ds.data.jma.go.jp/tcc/tcc/products/elnino/ cobesst/cobe-sst.html (Ishii et al., 2013; last access: 15 February 2019). Monthly mean HIRS OLR data can be obtained from NOAA website https://www.ncdc.noaa.gov/cdr/atmospheric/ outgoing-longwave-radiation-monthly (Lee and NOAA CDR Program, 2018; last access: 16 February 2019). The GPCP monthly mean precipitation dataset can be obtained from the NOAA website https://www.esrl.noaa.gov/psd/data/gridded/data.gpcp.html (Adler et al., 2003; last access: 16 February 2019). The AMSU/MHS data are available at NOAA's Comprehensive Large Array Data Stewardship System. In this work, AMSU/MHS raw data were obtained with support from the INSU-CNES French Mixed Service Unit ICARE/climserv/AERIS and accessed with the help of ESPRI/IPSL.

Author contributions. The text was written by KK and RU, and the figures were produced by NE, BMF, YK, and CK. CC contributed to the interpretation of the results.

Competing interests. The authors declare that they have no conflict of interest.

Acknowledgements. The authors wish to express their thanks to Leonhard Pfister and Shigeo Yoden for valuable discussions and comments. This work was supported in part by Grants-in-Aid for Scientific Research (25340010, 26281016, and 16H01184) from the Japan Society for the Promotion of Science. Preliminary analysis of this study was carried out using Interactive Tool for Analysis of Climate System, ITACS, provided by the Japan Meteorological Agency.

Edited by: Peter Haynes

Reviewed by: two anonymous referees

\section{References}

Abalos, M., Legras, B., Ploeger, F., and Randel, W. J.: Evaluating the advective Brewer-Dobson circulation in three reanalyses for the period 1979-2012, J. Geophys. Res.-Atmos., 120, 75347554, https://doi.org/10.1002/2015JD023182, 2015.

Adler, R. F., Huffman, G. J., Chang, A., Ferraro, R., Xie, P., Janowiak, J. E., Rudolf, B., Schneider, U., Curtis, S., Bolvin, D. T., Gruber, A., Susskind, J., Arkin, P. A., and Nelkin, E. J.: The Version 2 Global Precipitation Climatology Project (GPCP) monthly precipitation analysis (1979-present), J. Hydrometeorol., 4, 1147-1167, 2003.

Allen, R. J., Norris, J. R., and Kovilakam, M.: Influence of anthropogenic aerosols and the Pacific Decadal Oscillation on tropical belt width, Nat. Geosci., 7, 270-274, https://doi.org/10.1038/ngeo2091, 2014.

Aumann, H. H. and Ruzmaikin, A.: Frequency of deep convective clouds in the tropical zone from 10 years of AIRS data, Atmos. Chem. Phys., 13, 10795-10806, https://doi.org/10.5194/acp-1310795-2013, 2013.

Amaya, D. J., Siler, N., Xie, S.-P., and Miller, A. J.: The interplay of internal and forced modes of Hadley Cell expansion: Lessons from the global warming hiatus, Clim. Dynam., 51, 305-319, https://doi.org/10.1007/s00382-017-3921-5, 2018.

Brandt, M., Mbow, C., Diouf, A. A., Verger, A., Samimi, C., and Fensholt, R.: Ground and satellite based evidence of the biophysical mechanisms behind the greening Sahel, Glob. Change Biol., 21, 1-11, https://doi.org/10.1111/gcb.12807, 2014.

Byrne, M. P., Pendergrass, A. G., Rapp, A. D., and Wodzicki, K. R.: Response of the intertropical convergence zone to climate change: Location, width, and strength, Curr. Clim. Change Rep., 4, 355-370, https://doi.org/10.1007/s40641-018-0110-5, 2018.

Chiang, J. C. and Vimont, D. J: Analogous Pacific and Atlantic meridional modes of tropical atmosphere-ocean variability, J. Climate, 17, 4143-4158, 2004.

Davis, S. M. and Rosenlof, K. H.: A multidiagnostic intercomparison of tropical-width time series using reanalyses and satellite observations, J. Climate, 25, 1061-1078, 2012.

Diawara, A., Tachibana, Y., Oshima, K., Nishikawa, H., and Ando, Y.: Synchrony of trend shifts in Sahel boreal summer rainfall and global oceanic evaporation, 1950-2012, Hydrol. Earth Syst. Sci., 20, 3789-3798, https://doi.org/10.5194/hess-20-3789-2016, 2016.

Dima, I. and Wallace, J. M.: On the seasonality of the Hadley Cell, J. Atmos. Sci., 60, 1522-1527, 2003.

Dong, B. and Dai, A.: The influence of the interdecadal Pacific oscillation on temperature and precipitation over the globe, Clim. Dynam., 45, 2667-2681, 2015.

Eguchi, N., Kodera, K., and Nasuno, T.: A global non-hydrostatic model study of a downward coupling through the tropical tropopause layer during a stratospheric sudden warming, Atmos. Chem. Phys., 15, 297-304, https://doi.org/10.5194/acp-15-2972015, 2015.

Emanuel, K., Solomon, S., Folini, D., Davis, S., and Cagnazzo, C.: Influence of tropical tropopause layer cooling on Atlantic hurricane activity, J. Climate, 26, 2288-2301, https://doi.org/10.1175/JCLI-D-12-00242.1, 2013.

England, M. H., McGregor, S., Spence, P., Meehl, G. A., Timmermann, A., Cai, W., Gupta, A. S., McPhaden, M. J., Purich, A., and Santoso, A.: Recent intensification 
of wind-driven circulation in the Pacific and the ongoing warming hiatus, Nat. Clim. Change, 4, 222-227, https://doi.org/10.1038/nclimate2106, 2014.

Fontaine, B., Roucou, P., Gaetani, M., and Marteau, R.: Recent changes in precipitation, ITCZ convection and northern tropical circulation over North Africa (1979-2007), Int. J. Climatol., 31, 633-648, https://doi.org/10.1002/joc.2108, 2011.

Funatsu, B. M., Claud, C., Keckhut, P., Hauchecorne, A., and Leblanc, T.: Regional and seasonal stratospheric temperature trends in the last decade (2002-2014) from AMSU observations, J. Geophys. Res.-Atmos., 121, 8172-8185, https://doi.org/10.1002/2015JD024305, 2016.

Gaetani, M., Flamant, C., Bastin, S., Janicot, S., Lavaysse, C., Hourdin, F., Braconnot, P., and Bony, S.: West African monsoon dynamics and precipitation: the competition between global SST warming and $\mathrm{CO}_{2}$ increase in $\mathrm{CMIP}_{5}$ idealized simulations, Clim. Dynam., 48, 1353-1387, https://doi.org/10.1007/s00382016-3146-z, 2016.

Gautam, D. K. and Regmi, S. K.: Recent trends in the onset and withdrawal of summer monsoon over Nepal, ECOPERSIA, 1, 353-367, 2013.

Hagos, S. M. and Cook, K. H.: Dynamics of the West African monsoon jump, J. Climate, 20, 5264-5284, https://doi.org/10.1175/2007JCLI1533.1, 2007.

Hong, G., Heygster, G., Miao, J., and Kunzi, K.: Detection of tropical deep convective clouds from AMSU-B water vapor channels measurements, J. Geophys. Res., 110, D05205, https://doi.org/10.1029/2004JD004949, 2005.

$\mathrm{Hu}, \mathrm{S}$. and Fedorov, A. V.: The extreme El Niño of 2015-2016 and the end of global warming hiatus, Geophys. Res. Lett., 44, 38163824, https://doi.org/10.1002/2017GL072908, 2017.

$\mathrm{Hu}$, Y., Huang, H., and Zhou, C.: Widening and weakening of the Hadley circulation under global warming, Sci. Bull., 63, 640644, https://doi.org/10.1016/j.scib.2018.04.020, 2018.

IPCC: Summary for Policymakers, in: Climate Change 2013: The Physical Science Basis. Contribution of Working Group I to the Fifth Assessment Report of the Intergovernmental Panel on Climate Change, edited by: Stocker, T. F., Qin, D., Plattner, G.-K., Tignor, M., Allen, S. K., Boschung, J., Nauels, A., Xia, Y., Bex, V., and Midgley, P. M., Cambridge University Press, Cambridge, United Kingdom and New York, NY, USA, 2013.

Ishii, M., Shouji, A., Sugimoto, S., and Matsumoto, T.: Objective analyses of sea-surface temperature and marine meteorological variables for the 20th century using ICOADS and the KOBE collection, Int. J. Climatol., 25, 865-879, 2005.

Johnson, N. C.: How many ENSO flavors can we distinguish?, J. Climate, 26, 4816-4827, https://doi.org/10.1175/JCLI-D-1200649.1, 2013.

Kajikawa, Y., Yasunari, T., Yoshida, S., and Fujinami, H.: Advanced Asian summer monsoon onset in recent decades, Geophys. Res. Lett., 39, L03803, https://doi.org/10.1029/2011GL050540, 2012.

Kamae, Y., Li, X., Xie, S.-P., and Ueda, H.: Atlantic effects on recent decadal trends in global monsoon, Clim. Dynam., 49, 3443 3455, https://doi.org/10.1007/s00382-017-3522-3, 2017.

Kang, S. M. and Polvani, L. M.: The interannual relationship between the latitude of the eddy-driven jet and the edge of the Hadley cell, J. Climate, 24, 564-568, 2011.
Kao, H.-Y. and Yu, J.-Y.: Contrasting eastern-Pacific and central-Pacific types of ENSO, J. Climate, 22, 615- 632, https://doi.org/10.1175/2008JCLI2309.1, 2009.

Kobayashi, C. and Iwasaki, T.: Brewer-Dobson circulation diagnosed from JRA-55, J. Geophys. Res.-Atmos., 121, 1493-1510, https://doi.org/10.1002/2015JD023476, 2016.

Kobayashi, S., Ota, Y., Harada, Y., Ebita, A., Moriya, M., Onoda, H., Onogi, K., Kamahori, H., Kobayashi, C., Endo, H., Miyaoka, K., and Takahashi, K.: The JRA-55 Reanalysis: general specifications and basic characteristics, J. Meteorol. Soc. Jpn., 93, 5-48, https://doi.org/10.2151/jmsj.2015-001, 2015.

Kodera, K., Funatsu, B. M., Claud, C., and Eguchi, N.: The role of convective overshooting clouds in tropical stratospheretroposphere dynamical coupling, Atmos. Chem. Phys., 15, 67676774, https://doi.org/10.5194/acp-15-6767-2015, 2015.

Kosaka, Y. and Xie, S.-P.: Recent global-warming hiatus tied to equatorial Pacific surface cooling, Nature, 501, 403-407, https://doi.org/10.1038/nature12534, 2013.

Kuroda, Y.: An effective SVD calculation method for climate analysis, J. Meteorol. Soc. Jpn., 76, 647-655, 1998.

Lee, H., Gruber, A., Ellingson, R. G., and Laszlo, I.: Development of the HIRS outgoing longwave radiation climate dataset, J. Atmos. Ocean. Tech., 24, 2029-2047, https://doi.org/10.1175/2007JTECHA989.1, 2007.

Lee, H.-T. and NOAA CDR Program: NOAA Climate Data Record (CDR) of Monthly Outgoing Longwave Radiation (OLR), Version 2.7, NOAA National Centers for Environmental Information, https://doi.org/10.7289/V5W37TKD, 2018.

Li, J., Wolf, W. W., Menzel, W. P., Zhang, W., Huang, H., and Achtor, T. H.: Global soundings of the atmosphere from ATOVS measurements: The algorithm and validation, J. Appl. Meteorol., 39, 1248-1268, https://doi.org/10.1175/15200450(2000)039<1248:GSOTAF>2.0.CO;2, 2000.

Liu, B. and Zhou, T., Atmospheric footprint of the recent warming slowdown, Scientific Reports, 7, 40947, https://doi.org/10.1038/srep40947, 2017.

Liu, C. and Zipser, E. J.: Global distribution of convection penetrating the tropical tropopause, J. Geophys. Res., 110, D23104, https://doi.org/10.1029/2005JD006063, 2005.

Lucas, C., Timbal, B., and Nguyen, H.: The expanding tropics: A critical assessment of the observational and modeling studies, WIREs Clim. Change, 5, 89-112, https://doi.org/10.1002/wcc.251, 2013.

Maidment, R. I., Allan, R. P., and Black, E.: Recent observed and simulated changes in precipitation over Africa, Geophys. Res. Lett., 42, 8155-8164, https://doi.org/10.1002/2015GL065765, 2015 .

Meehl, G. A., Hu, A., Arblaster, J. M., Fasullo, J., and Trenberth, K. E.: Externally forced and internally generated decadal climate variability associated with the interdecadal Pacific oscillation, J. Climate, 26, 7298-7310, https://doi.org/10.1175/JCLI-D-1200548.1, 2013.

Paek, H., Yu, J.-Y., and Qian, C.: Why were the 2015/2016 and 1997/1998 extreme El Niños different?, Geophys. Res. Lett., 44, 1848-1856, https://doi.org/10.1002/2016GL071515, 2017.

Ramsay, H.: The effects of imposed stratospheric cooling on the maximum intensity of tropical cyclones in axisymmetric radiative-convective equilibrium, J. Climate, 26, 9977-9985, https://doi.org/10.1175/JCLI-D-13-00195.1, 2013. 
Randel, W. J. and Jensen, E. J. : Physical processes in the tropical tropopause layer and their roles in a changing climate, Nat. Geosci., 6, 169-176, https://doi.org/10.1038/ngeo1733, 2013.

Randel, W. J., Wu, F., Vömel, H., Nedoluha, G. E., and Forster, P.: Decreases in stratospheric water vapor after 2001: links to changes in the tropical tropopause and the Brewer-Dobson circulation, J. Geophys. Res., 111, D12312, https://doi.org/10.1029/2005JD006744, 2006.

Seidel, D. J., Fu, Q., Randel, W. J., and Reichler, T. J.: Widening of the tropical belt in a changing climate, Nat. Geosci., 1, 21-24, https://doi.org/10.1038/ngeo.2007.38, 2007.

Schneider, T.: Feedback of atmosphere-ocean coupling on shifts of the Intertropical Convergence Zone, Geophys. Res. Lett., 44, 11644-11653, https://doi.org/10.1002/2017GL075817, 2017.

Seviour, W. J. M., Butchart, N., and Hardiman, S.C.: The BrewerDobson circulation inferred from ERA-Interim, Q. J. Roy. Meteor. Soc., 138, 878-888, https://doi.org/10.1002/qj.966, 2012.

Stuecker, M. F.: Revisiting the Pacific meridional mode, Scientific Reports, 8, 3216, https://doi.org/10.1038/s41598-018-21537-0, 2018.

Taylor, C. M., Belušić, D., Guichard, F., Parker, D. J., Vischel, T., Bock, O., Harris, P. P., Janicot, S., Klein, C., and Panthou, G.: Frequency of extreme Sahelian storms tripled since 1982 in satellite observations, Nature, 544, 475-478, https://doi.org/10.1038/nature22069, 2017.

Trenberth, K. E.: Has there been a hiatus?, Science, 349, 691-692, 2015.

Trenberth, K. E., Fasullo, J. T., Branstator, G., and Phillips, A.: Seasonal aspects of the recent pause in surface warming, Nat. Clim. Change, 4, 911-916, https://doi.org/10.1038/nclimate2341, 2014.

Urabe, Y., Yasuda, T., and Maeda, S.: Rapid warming in global sea surface temperature since around 2013, SOLA, 13, 25-30, https://doi.org/10.2151/sola.2017-005, 2017.

Vizy, E. K. and Cook, K. H.: Understanding longterm (19822013) multidecadal change in the equatorial and subtropical South Atlantic climate, Clim. Dynam., 46, 2087, https://doi.org/10.1007/s00382-015-2691-1, 2016.
Waliser, D. E. and Gautier, C.: A satellite-derived climatology of the ITCZ, J. Climate, 6, 2162-2174, 1993.

Wang, B., Liu, J., Kim, H.-J., Webster, P. J., Yim, S.-Y., and Xiang, B.: Northern Hemisphere summer monsoon intensified by mega-El Niño/southern oscillation and Atlantic multidecadal oscillation, P. Natl. Acad. Sci. USA, 110, 5347-5352, 2013.

Wang, S., Camargo, S. J., Sobel, A. H., and Polvani, L. M.: Impact of the tropopause temperature on the intensity of tropical cyclones - an idealized study using a mesoscale mode, J. Atmos. Sci., 71, 4333-4348, 2014.

Watanabe, M., Shiogama, H., Tabete, H., Hayashi, M., Ishii, M., and Kimoto, M.: Contribution of natural decadal variability to global warming acceleration and hiatus, Nat. Clim. Change, 4, 893-897, https://doi.org/10.1038/nclimate2355, 2014.

Wodzicki, K. R. and Rapp, A. D.: Long-term characterization of the Pacific ITCZ using TRMM, GPCP, and ERA-Interim, J. Geophys. Res.-Atmos., 121, 3153-3170, https://doi.org/10.1002/2015JD024458, 2016.

Xiang, B. and Wang, B.: Mechanisms for the advanced Asian summer monsoon onset since the mid-to-late 1990s, J. Climate, 26, 1993-2009, 2013.

Xie, S.-P.: The shape of continents, air-sea interaction, and the rising branch of the Hadley circulation, in: The Hadley Circulation, Past, Present and Future, edited by: Diaz, H. F. and Bradley, R. S., Kluwer Academic Publishers, Dordrecht, the Netherlands, 121152, 2004.

Xie, S.-P. and Kosaka, Y.: What caused the global surface warming hiatus of 1998-2013?, Curr. Clim. Change Rep., 3, 128-140, https://doi.org/10.1007/s40641-017-0063-0, 2017.

Xie, S.-P. and Philander, S. G. H.: A coupled ocean-atmosphere model of relevance to the ITCZ in the eastern Pacific, Tellus A, 46, 340-350, 1994.

Yun, K.-S., Lee, J.-Y., and Ha, K.-J.: Recent intensification of the South and East Asian monsoon contrast associated with an increase in the zonal tropical SST gradient, J. Geophys. Res.-Atmos., 119, 8104-8116, https://doi.org/10.1002/2014JD021692, 2014. 